\title{
Influence of financial attitude, financial behavior, financial capability on financial satisfaction
}

\author{
Agus Zainul Arifin \\ Tarumanagara University, Jakarta, Indonesia
}

\begin{abstract}
This research aims to examine the influence of Financial Attitude, Financial Behavior, and Financial Capability on Financial Satisfaction. This research was conducted on workers in Jakarta, Indonesia. The Sampling method used a non-probability sampling of purposive sampling. Data were obtained by spreading online questionnaire through Google questionnaire. The data was processed using SmartPLS 3.0. The result suggested that Financial Attitude, Financial Behavior, and Financial Capability have a positive relationship on Financial Satisfaction.
\end{abstract}

Keywords: financial capability, financial attitude, financial behavior, financial satisfaction

\section{INTRODUCTION}

Satisfaction is one form of happiness obtained from the result of an effort that has been carried out by someone. The happiness of life is the crowning achievement of any result. One form of happiness is through the achievement of financial satisfaction. Financial satisfaction is derived from a form of someone's behavior that is associated with how these people manage their revenues in order to meet their financial needs. Financial need is said to be successful if the individual is able to meet short-term needs for consumption and long-term needs without the slightest deficiency.

Financial satisfaction can be explained using the theory of financial behavior. This theory is based on the Theory of Planned Behavior (TPB) that explains about individual behavior arises because of the intention. TPB explains that one's behavior emerges from the existence of intention. The intention is influenced by one's attitude based on how important the behavior of the individual. Behavior intention of someone is influenced by normative properties. This property is an individual's perception of what should one do according to others in which he deems important (Ajzen 1991). An individual's desire is de- termined by two independent variables which are attitude and subjective norm (Ajzen \& Fishbein 1980). Attitude is a subjective norm because of the social pressure that an individual feels to do or not to do an action. Subjective norm is a normative belief which expresses individual motivation to abide referred groups. The individual behavioral control perception shows the acceptability for one to cross a border (Ajzen 1991).

Ajzen \& Fishbein (1980) stated that TPB emerges from Theory of Reasoned Action or TRA for short. TRA states that subjective norm is a social evolution which dictates human's life which is used to approve or disapprove certain acts. This rule is based on a belief called normative belief. Family environment factor is an environment that can influence individual's actions or behavior. One would commit an action if other people deem that the said action is positive, acceptable or not.

Financial satisfaction is obtained by the individuals if the desire to obtain something is achieved from their financial condition and environmental condition supports the action. Financial satisfaction shows one's satisfaction with their current financial condition (Zimmerman 1995). The more satisfied a person with their personal financial condition then the indi- 
vidual will become more satisfied and happier (Toscano et al. 2006). People with high income tend to have their financial satisfaction fulfilled.

There are lots of factors influencing financial satisfaction, which are financial attitude, financial behavior, and financial capability. Financial Attitude is a psychological tendency which is expressed when evaluating financial management practice that is recommended by the level of deal or no deal (Jodi \& Phyllis 1998).

Financial attitude is defined as a state of mind, opinion, and judgment about finance (Pankow 2012). These things are parts of attitude which are inseparable from the human mind that can influence the financial decision making that affects financial satisfaction. According to Falahati et al. (2012), the financial attitude has a significant influence on financial satisfaction.

Financial behavior reflects on how human's behavior is relevant to financial management (Xiao 2009). The goal of financial behavior is to understand and predict the systematic implications of the financial market from the psychological point of view. Some researchers state that financial behavior influences financial satisfaction (Joo \& Grable 2004, Coskuner 2016).

Financial capability is one's ability to manage and control finance (Taylor 2011). It is acceptable to assume that financial capability is self-efficacy financial. Self-efficacy is an important psychological factor that affects human's behavior. Self-efficacy is related to the judgment of how well an individual can perform an action which is necessary to deal with the prospective situation. There are some fields of financial capability which affect financial satisfaction that is associated with knowledge, understanding, skill, belief, and attitude (Kempson et al. 2005). Financial capability is associated with the ability to use finance to gain what is desired to achieve financial wellness. If each and every customer could manage their financial capability effectively, an individual wouldn't only able to satisfy their current needs, but also their future needs, which lead to the achievement of financial satisfaction.

The purpose of this research is to see the influence of financial attitude (FA), financial behavior (FB), and financial capability (FC) on financial satisfaction (FS). The sample that was used was the workers in Jakarta in 2017. Researchers used a sample of workers in Jakarta because their income is relatively high, their knowledge about financial literacy is higher than workers in the smaller cities, and they can easily invest because many facilities are available.

This research is a combination of researches done by Coskuner (2016), Falahati et al. (2012),
Woodyard \& Robb (2016), Robb \& Woodyard (2011), Chandra \& Memarista (2015), Halim \& Astuti (2015) and Joo \& Grable (2004).

\section{METHOD}

The subjects of this research were workers in Jakarta in 2017. They were workers that had fixed income per month, which consist of employees of public and private companies, professional, and entrepreneurs.

Indicators used for financial satisfaction according to Hira \& Mugenda (1998) explained that financial satisfaction can be measured by several things: (1) savings, (2) debt, (3) the current financial situation, (4) the ability to meet long-term needs, (5) the funds for emergency situation, and (6) the financial management skills. Joo \& Grable (2004) and Toscano et al. (2006) measure financial satisfaction with one question that is "How satisfied are you with your current financial condition?"

Indicators used for financial attitude according to Rajna et al. (2011) explained that financial attitude can be measured by 11 financial statements, namely: (1) It is important for me to develop a regular pattern of savings and stick to it; (2) I should have written financial goals that help me set priorities in spending; (3) Written budget is essential for successful financial management; (4) Each individual must take responsibility for their own financial well-being; (5) Saving is not important; (6) As long as I make the monthly payments, I do not have to worry about the length of my time to pay off the debt; (7) I don't care about how much I have saved for my savings; (8) Financial planning for retirement is not necessary to ensure the safety of a person during old age; (9) It is important to plan for possible disability salary; (10) Ensuring my property is insured against a reasonable risk is necessary for successful financial management; and (11) Thinking about where I will be financially in 5 or 10 years in time is very important for financial success.

Kholilah \& Iramani (2013) measured financial behavior with: (1) expenditures, (2) bills payment, (3) financial planning, (4) providing money for self and family, and (5) savings.

Indicator used for financial capability were: (1) Expense fulfillment, (2) Household needs, (3) Managing finance, (4) Financial condition, and (5) Savings (Xiao et al. 2014)

The data were primary data. Data obtained by spreading online questionnaire via Whatsapp, Facebook, and email. The questionnaire was made with Google Doc app. The sample data collected were 450 respondents. 
The collected data was analyzed using SmartPLS-Pro Version 3.0 software. Statistical analysis tools used inner and outer model analysis. The analysis was conducted to test the research hypothesis.

\section{DISCUSSIONS}

Statistical analysis used in this research was to test the feasibility of the measuring instrument and to test the research hypothesis. The feasibility test of the measuring instrument was done by testing the Outer Model (the validity and reliability testing). Meanwhile, to test the research hypothesis, inner Model was deployed. The structural model in this study is shown in Figure 1.

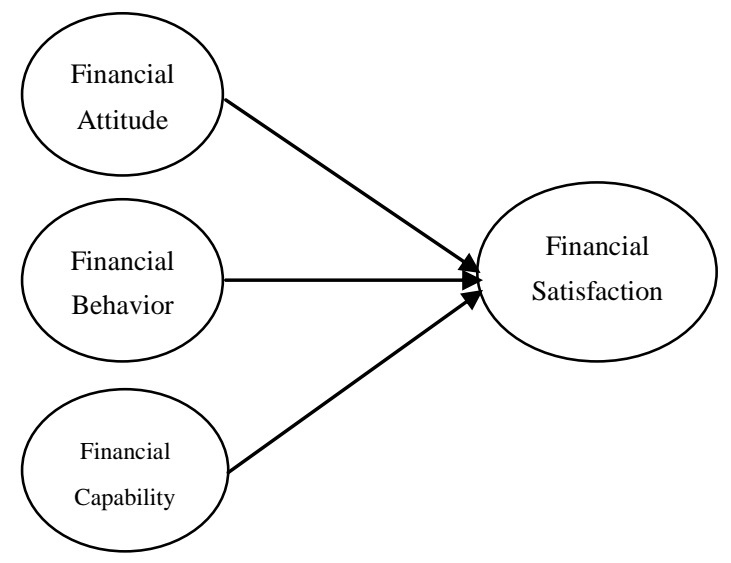

Figure 1. Research Structural Model

Figure 1 shows the relationship between independent and dependent variables. Independent variables consist of Financial Attitude (FA) with four indicators. Financial Behavior contains five indicators. Financial Capability contains five indicators. Dependent Variable Financial Satisfaction used six indicators.

The outer model test is used to test the validity and reliability. The Convergent Test and Discriminant test were deployed to test validity. Composite reliability test and Cronbach's alpha were used to test reliability. The convergent test used the loading factor. This test obtained three indicators that were not valid because the loading factor value was smaller than 5\%; the indicators were the FC1, FC2, and FS4 indicators. After the three indicators were discarded, the result became valid. This was supported by Discriminant test which also stated valid. The result of composite reliability test and Cronbach's alpha tested reliability. Composite reliability test and Cronbach's alpha were all reliable variables because the composite value and Cronbach's alpha value were above 0.7 .

Structural model test (inner model) was used to test the research hypothesis to know whether certain variable influences another variable according to the constructed structural model (figure 1). The inner model test was done by bootstrapping test to measure the coefficient of determination, the contribution of indicator to a variable, hypothesis testing (t-test Statistic), and goodness of fit test. Structural model test results are presented in equation (1)

$$
\begin{aligned}
& \mathrm{FS}=0,235 . \mathrm{FA}+0.222 . \mathrm{FB}+0,207 . \mathrm{FC} \\
& \text { P-Value 3,753*** 3,655*** 3,567*** } \\
& \text { F-test: NFI }=0,696 \\
& \mathrm{R}^{2} \quad=0,330
\end{aligned}
$$

From Equation (1), the result of t-test by using a p-Value indicator with alpha value is less than $1 \%$ $(* * * *)$ and has a positive relationship. Thus, the accepted hypotheses are FA, FB, and FC has a positive effect on FS.

Model test obtained NFI value 0.696 . The model is considered fit if the value of NFI $>0.5$. So, it can be said that the research model is fit. Independent variable as a whole is subject to a dependent variable with the contribution of $33.00 \%$.

The analysis result states that the Financial Attitude has a positive effect on Financial Satisfaction. This relationship signifies the better the individual in managing his finance, the higher the financial satisfaction is achieved. This is demonstrated by the ability to earn income and expenditure, to get used to saving, to have goals in finance, and to saturate financial plans for the future. Education is very instrumental in one's attitude. More than $60 \%$ of the respondents in this sample have an undergraduate educational background. An individual with a high educational background will tend to have a good knowledge of finance so that people will know how to deal with financial management well in order to achieve prosperity and financial satisfaction. The results of this study are in accordance with Chandra \& Memarista (2015) study which states that the financial attitude is positively related to financial satisfaction.

Statistic test proves that Financial Behavior has a positive effect on Financial Satisfaction. This means that the better an individual manages his finances in financial behavior, the higher the financial satisfaction will be. The results show that respondents have good financial behavior, so as to control expenses, they pay bills on time, make plans for the future, and save some money. The results of this study are in accordance with Xiao et al. (2014), Halim \& Astuti (2015) and Joo \& Grable (2004). But contrary to the outcome of Herdjiono \& Damanik (2016) which stated that the current financial behavior of Indonesian society tends to be more consumptive and results in lack of savings activities, investment, emergency fund planning, and budgeting for the future. 
Based on the results of this research, there is a positive relationship between Financial Capability and Financial Satisfaction which means that the greater the ability of an individual in managing his financial condition, the higher the financial satisfaction will be. This is shown from the ability of an individual in managing his finances for daily needs. The results of this study are in accordance with Xiao et al. (2014) stating that financial capability is positively related to financial satisfaction.

\section{CONCLUSION}

Based on the literature review and the analysis, then it is safe to assume that financial attitude, financial behavior, and financial capability, whether as an individual or as a group have an influence on Financial Satisfaction.

\section{REFERENCES}

Ajzen, I. 1991. The theory of planned behavior. Organizational Rohavinr and Human Doricion Prorossos 50(7). 179_-711

Ajzen, I. \& Fishbein, M. 1980. Understanding attitudes and predicting social behavior. Englewood Cliffs, NJ: PrenticeHall.

Chandra, J.W. \& Memarista, G. 2015. Faktor-Faktor yang Mempengaruhi Financial Satisfaction pada Mahasiswa Universitas Kristen Petra. FINESTA 3(2): 1-6.

Coskuner, D.S. 2016. Understanding Factors Affecting Financial Satisfaction: The Influence of Financial Behavior, Financial Knowledge and Demographics. Imperial Journal of Interdisciplinary Research 2(5): 377-385.

Falahati, L., Sabri, M.F. \& Paim, L.H. 2012. Assessment a Model of Financial Satisfaction Predictors: Examining the Mediate Effect of Financial Behaviour and Financial Strain. World Applied Sciences Journal 20(2): 190-197.

Halim, Y.K. \& Astuti, D. 2015. Financial Stressors, Financial Behavior, Risk Tolerance, Financial Solvency, Financial Knowledge, dan Kepuasan Finansial. FINESTA 3(1): 19-23.

Herdjiono, I. \& Damanik, L.A. 2016. Pengaruh Financial Attitude, Financial Knowledge, Parental Income Terhadap Financial Management Behavior. Jurnal Manajemen Teori dan Terapan 9(3): 226-241.

Hira, T.K. \& Mugenda, O.M. 1998. Predictor of financial satisfaction: Differences between retirees and non-retirees. Financial Counseling and Planning 9(2): 75-83.

Kempson, E., Collard, S. \& Moore, N. 2005. Measuring financial capability: an exploratory study. London: Financial Services Authority.

Kholilah, N.A. \& Iramani. R. 2013. Studi Financial Management Behavior Pada Masyarakat Surabaya. Journal of Business and Banking 3(1): 69-80

Jodi, L.P. \& Phyllis, J.J. 1998. The impact of financial attitude and knowledge on financial management and satisfaction of recently married individuals. Association for Financial Counselling and Planning 9(2).

Joo, S. \& Grable, J.E. 2004. An Exploratory Framework of the Determinants of Financial Satisfaction. Journal of Family and Economic Issues 25(1): 25-50.
Pankow, D. 2012. Financial Values, Attitudes, and Goals. Family Economic Specialist, NDSU.

Rajna, A., Ezat, W.P.S., Junid, S.A., Moshiri, H. 2011. Financial Management Attitude and Practice among the Medical Practitioners in Public and Private Medical Service in Malaysia. International Journal of Business and Management 6(8): 105-113.

Robb, C.A., \& Woodyard, A.S. 2011. Financial Knowledge and Best Practice Behavior. Journal of Financial Counseling and Planning 22(1): 60-70.

Taylor, M. 2011. Measuring financial capability and its determinants using survey data. Social Indicators Research 102(2): 297-314

Toscano, E.V., Amestoy, V.A. \& Del Rosal, R.S. 2006. Building Financial Satisfaction. Social Indicators Research 77(2): 211-243.

Woodyard, A.S. \& Robb, C.A. 2016. Consideration of Financial Satisfaction: What Consumers Know, Feel and Do from a Financial Perspective. Journal of Financial Therapy 2(4): 41-61.

Xiao, J.J. 2009. Applying behavior theories to financial behavior. Handbook of consumer finance and research 6981.

Xiao, J.J., Chen, C. \& Chen, F. 2014. Consumer financial capability and financial satisfaction. Social Indicators Research 118: 415-432.

Zimmerman, S.L. 1995. Understanding Family Policy: Theories and Applications 2nd ed. California: Thousand Oaks. 